\title{
ELABORACIÓN DE PROPUESTAS DIDÁCTICAS ORIENTADAS A MEJORAR LOS PROGRAMAS SOCIOEDUCATIVOS PARA JÓVENES EN SITUACIÓN DE RIESGO SOCIAL
} MAKING DIDACTIC PROPOSALS AIMED AT IMPROVING SOCIOEDUCATIONAL PROGRAMS FOR YOUNGSTERS AT RISK OF SOCIAL EXCLUSION

\section{ELABORAÇAO DE PROPOSTAS DIDÁCTICAS \\ PARA MELHORAR PROGRAMAS SOCIO-EDUCATIVOS PARA JOVENS EM SITUAÇAO DE RISCO SOCIAL}

\author{
María Violeta Álvarez Fernández, Víctor Raúl Pintado Rey \\ y José Luis San Fabián Maroto \\ UNIVERSIDAD DE OVIEDO, ESPAÑA
}

RESUMEN: Los educadores y educadoras de la Casa Juvenil de Sograndio (Centro de Internamiento de Menores para la Ejecución de Medidas Judiciales del Principado de Asturias), convencidos de que podían aportar alternativas para mejorar su intervención socioeducativa, se implicaron en un proceso formativo de Investigación-Acción orientado a elaborar propuestas didácticas que pudiesen contribuir a optimizar el desarrollo de los programas de competencia social dirigidos a jóvenes con conductas delictivas.

Para ello, se aplicó el Programa de Pensamiento Prosocial Versión Corta para Jóvenes PPS-VCJ (Alba et al., 2005) a 9 internos, 8 varones de entre catorce y veinte años y 1 chica de dieciséis, como base de análisis y reflexión de nuestra intervención metodológica. El equipo de investigación consta de 9 educadores internos y 3 externos (2 coordinadores y 1 psicóloga).

La investigación, predominantemente cualitativa, incorpora diversos instrumentos cuantitativos y cualitativos, como los registros de observación, los grupos de discusión, los cuestionarios y la libreta de notas.

Tras la implementación del programa, destacan los cambios positivos en la dimensión emocional, resolución de conflictos, autocontrol y tolerancia a la frustración. Se observa también altos niveles de satisfacción en jóvenes, educadores/as e informantes externos.

Cabe señalar la importancia de haber conseguido crear un clima de compromiso profesional para el cambio, abandonando una actitud pasiva ante la formación, para iniciar una búsqueda activa de respuestas prácticas, ajustadas a sus necesidades e intereses profesionales. Finalmente, realizamos unas reflexiones y propuestas de actuación dirigidas a generar conocimiento didáctico pensado y adaptado a la educación social. 
PALABRAS CLAVE: Educación social; delincuencia juvenil; investigación-acción; intervención didáctica; pensamiento prosocial; programas educativos.

ABSTRACT: Educators at Sograndio Juvenile Detention Center in Asturias were sure that they were able to offer new alternatives to improve their socio-educational intervention. That is the reason why they got involved in an action research training process aimed at making didactic proposals which tried to optimize the development of social competence programs for youngsters with criminal behavior.

In order to do this, the Short Version of the Prosocial Thinking Program for Young People (Alba et al., 2005) was applied to nine inmates, eight males between 14 and 20 years old and a female of 16 years old. They were the basis and reflection of our methodological intervention. The team taking part in this intervention is formed by nine inmates and three external members (two coordinators and a woman psychologist).

The investigation, mainly qualitative, includes different instruments (both qualitative and quantitative), such as: observation registries, discussion groups, questionnaires and notebooks.

After the implementation of the program, positive changes must be highlighted in the emotional dimension, the resolution of problems, self-control and frustration tolerance. Besides, very high levels of satisfaction have been observed among youngsters, educators and external informants.

It is important to have created a climate of professional compromise towards change and this way to have abandoned a passive attitude towards training, so that we were able to start an active search for practical answers, adjusted to our necessities and professional interests. Finally, we make several observations and intervention proposals that contribute to generate didactic knowledge thought and adapted for social education.

KEYWORDS: Community education; juvenile delinquency; educational intervention; prosocial thinking; educational programs.

RESUMO: Os educadores da Casa da Juventude Sograndio (Centro de internamento de jovens para a execuçao de medidas judiciais de Asturias), convencidos de que poderiam fornecer alternativas para melhorar a intervenção socioeducativa, foram envolvidos em um processo de formação de investigaçao-acçao que teve como objetivo a elaboração de propostas didácticas capazes de contribuir a otimizar o desenvolvimento de programas de habilidades sociais para jovens com comportamento criminoso.

Para fazer isso, foi aplicado o Programa de Pensamento pró-social versão curta para jovem PPS-VCJ (Alba et al., 2005) a 8 rapazes internos de 14 a vinte anos e 1 garota de 16, como base para a análise e reflexão da nossa metodologia de intervenção. A equipa participante é composto por 9 membros internos e 3 membros externos (2 coordenadores e um psicólogo).

A pesquisa, predominantemente qualitativa, incorpora vários registros quantitativos e qualitativos como registros de observação, grupos de discussão, questionários e caderno.

Após a implementação do programa, destacar as mudanças positivas na dimensão emocional, na resolução de conflitos, auto-controle e tolerância à frustração. Há também níveis muito elevados de satisfação em jovens, educadores e informantes externos.

Podemos notar a importância de ter conseguido criar um clima de compromisso profissional para a mudança, deixando uma abordagem passiva à formação, para iniciar uma busca ativa de respostas práticas, adaptadas às suas necessidades e interesses profissionais. Concluímos com algumas reflexões e propostas de ação que contribuam para o conhecimento didáctico projetado e adaptado para a educação social.

PALAVRAS-CHAVE: Educação comunitária; delinquência juvenil; investigação-acção; educativa; pensamento pró-social; programas educacionais.

[ 152 ] MARÍA VIOLETA ÁLVAREZ FERNÁNDEZ, VÍCTOR RAÚL PINTADO REY Y JOSÉ LUIS SAN FABIÁN MAROTO SIPS - PEDAGOGIA SOCIAL. REVISTA INTERUNIVERSITARIA [1139-1723 (2014) 23, 151-172] TERCERA ÉPOCA 


\section{Introducción}

Tomando como marco de investigación la aplicación de las 13 sesiones del Programa de Pensamiento Prosocial Versión Corta para Jóvenes PPS-VCJ (Alba et al., 2005), dirigido a jóvenes con conductas disruptivas, adaptamos su metodología y actividades a nuestro contexto educativo, con objeto de analizar su desarrollo y obtener unas orientaciones didácticas que permitan mejorar nuestra intervención socioeducativa en este tipo de programas.

Ya los autores del programa (López y Garrido, 2005) manifiestan que tan importante como su contenido es su forma de enseñarse. Aunque hasta la fecha existe poca bibliografía sobre «didáctica y educación social», en la actualidad algunos autores (Feliz Murias, Sepúlveda Barrios y Gonzalo Fernández, 2008; Forés y Vallvé, 2002; Parcerisa, 2004; Parcerisa, Giné y Forés, 2010) han comenzado a investigar esta relación que, aun estando todavía por consolidar, parece comenzar a brotar con fuerza.

McGuire y Priestley (1995), en sus principios para el diseño de los programas eficaces, establecen que los estilos de aprendizaje de la mayoría de los delincuentes requieren métodos activos y participativos de trabajo, en vez de métodos imprecisos y carentes de estructura. Por ello, decidimos tomar como marco de referencia las bases teóricas de la pedagogía francesa de Meirieu (2006, 2007, 2009), pedagogía que se caracteriza por su defensa de los métodos activos y la pedagogía diferenciada, donde los educadores están obligados a crear contextos con situaciones de aprendizaje, espacios, tiempos e instrumentos adaptados para que los jóvenes puedan aprender ( $O^{\prime}$ Connor y Seymour, 2003).

Esta apuesta didáctica exigía revisar y cuestionar nuestra praxis para poder proponer alternativas más activas que, sin descuidar la profundidad y el rigor de los contenidos, resultasen más atractivas.

\section{Diseño de la investigación}

Comenzamos exponiendo los objetivos de la investigación para pasar posteriormente a presentar los aspectos más relevantes del diseño metodológico.

\section{Introduction}

Regarding as research framework the implementation of the 13 sessions of Pro-social Thinking Program - Short Version for Youth - PTP-SVA (Alba et al., 2005) and aiming young people with disruptive behavior, the methodology and activities in the program were adapted to our educational context, so to analyze their development and obtain teaching guidelines to improve our socio-educational intervention in this type of program.

The program's authors (López Garrido, 2005) affirm that so important as the program's content is the way it is taught. Although until this day there is little literature on 'teaching and social education', currently some authors (Fores and Vallvé, 2002; Parcerisa, 2004; Happy Murias, Barrios and Gonzalo Fernández Sepúlveda, 2008; Parcerisa, Giné and Fores, 2010) have begun to investigate this relations which, despite still in process of consolidation, seems to be growing continuously.

McGuire \& Priestley (1995), in their principles of effective program designs establish that the learning styles of most delinquents require active and participatory methods of work, rather than vague and unstructured ones. Therefore, we decided to take as reference the theoretical basis of Meirieu's French pedagogy (2006, 2007, 2009), which is characterized by his defense of active methods and a differentiated pedagogy where educators are required to create contexts with learning situations, along with adequate space, time and instruments the youth to learn (O'Connor and Seymour, 2003).

This educational venture required revision and questioning of our practice in order to propose active alternatives that, without neglecting the depth and rigor of the subject, prove themselves more attractive.

\section{Research Design}

We shall begin exposing the research objectives before moving on to present the most relevant aspects of the methodology. 


\subsection{Objetivos}

Como objetivo general proponemos desarrollar un proceso formativo de reflexión y acción sobre la práctica en el ámbito de los programas del pensamiento prosocial orientados a jóvenes en situación de riesgo social.

Los objetivos específicos son los siguientes:

- Adaptar y desarrollar el Programa del Pensamiento Prosocial Versión Corta para Jóvenes a las características del centro y de sus internos.

- Valorar la influencia de distintas propuestas didácticas en la consecución de los objetivos de las sesiones y en las variables conductas disruptivas, interés y participación.

- Delimitar unos núcleos temáticos (metacategorías) para el análisis e interpretación de la intervención didáctica.

- Comprobar la eficacia del programa en función de los indicadores externos utilizados para la evaluación del mismo.

- Valorar la opinión y satisfacción que suscita el programa.

- Reducir las reticencias de los jóvenes hacia los programas de corte cognitivo, facilitándoles una experiencia previa positiva y motivadora.

- Elaborar propuestas didácticas de actuación que contribuyan a mejorar el éxito de los programas socioeducativos.

\subsection{Población y muestra}

Durante el periodo de investigación la población de jóvenes de la Casa Juvenil de Sograndio (Oviedo) oscila entre 22 y 28 internos, con edades comprendidas entre 14 y 20 años. La población femenina suele estar entre el $5 \%$ y $10 \%$.

La muestra de jóvenes se ha seleccionado a través de un proceso intencional no probabilístico con un criterio principal de partida: asegurar la asistencia de los internos a las sesiones de trabajo durante el trimestre de implementación del programa.

Al principio de la investigación cumplían este criterio 10 jóvenes, 9 varones (14-20 años) y una chica (16 años). No obstante, a partir de la quinta sesión del programa, una baja inesperada a causa de una finalización de medida no prevista provoca que la muestra final quede establecida en 9 sujetos.

\subsection{Objectives}

The main objective is to develop a learning process of reflection and action about the practice in the field of programs of pro-social thought attending youth under social risk.

The specific objectives are to:

- Adapt and develop the Program of Pro-social Thought Short Version for the Youth according to the characteristics of the centers and their inmates.

- Assess the influence of different educational proposals in achieving the session's objectives, and variables such as disruptive behavior, interest and participation.

- Delineate thematic concepts (metacategories) for the analysis and interpretation of the educational intervention.

- Test the effectiveness of the program in terms of external indicators used for its evaluation.

- Identify the opinions and satisfaction brought by the program.

- Reduce the reluctance of adolescents towards cognitive programs, providing positive prior experience and motivation.

- Develop educational proposals of intervention which help improve the achievements of socialeducational programs.

\subsection{Population and sample}

During the research period the youth population of Youth House Sograndio (Oviedo) ranged between 22 and 28 inmates, with ages between 14 and 20 years. The female population is usually between $5 \%$ and $10 \%$.

The sample of adolescents was selected through a non-probabilistic intentional process with a core starting point: to assure interns assistance in working sessions during the quarter in which the program was being implemented.

At the beginning of the investigation 10 adolescents met this standard: 9 boys ( $14-20$ years) and a girl (16 years). However, after the fifth session of the program, an unexpected shortening in number because of an unexpected sentence finalization caused the final sample to end up with 9 subjects.

[ 154 ] MARÍA VIOLETA ÁLVAREZ FERNÁNDEZ, VÍCTOR RAÚL PINTADO REY Y JOSÉ LUIS SAN FABIÁN MAROTO SIPS - PEDAGOGIA SOCIAL. REVISTA INTERUNIVERSITARIA [1139-1723 (2014) 23, 151-172] TERCERA ÉPOCA 
La población de educadores ronda las 23 personas, de las que 9, contando al educador-investigador, forman parte del equipo de investigación. Además, incorporamos como evaluadores externos a la psicóloga del centro y a los dos coordinadores educativos.

\subsection{Metodología de investigación}

Los objetivos planteados y las características del contexto de investigación nos han llevado a plantear una metodología ecléctica, con un predominio cualitativo que se complementa con instrumentos y análisis cuantitativos.

Dentro de la metodología cualitativa, la Investigación-Acción puede considerarse la base fundamental del estudio, destacando las distintas reuniones de trabajo conjuntas, dirigidas al análisis de los datos e
The numbers of teachers was approximately 23 persons, in which 9, including a teacher-researcher, made part of the research team. In addition, one psychologist and two educational coordinators from the detention center contributed as evaluators

\subsection{Research Methodology}

The objectives and characteristics of the research's context have led us to propose an eclectic methodology, predominantly qualitative in nature and complemented with quantitative analytic instruments.

In regard to qualitative methodology, Active Research may be considered the foundation of this study, as was made explicit by the realization of various joint workshops, focused on analyzing

Tabla 1. Momentos y estrategias metodológicas de evaluación

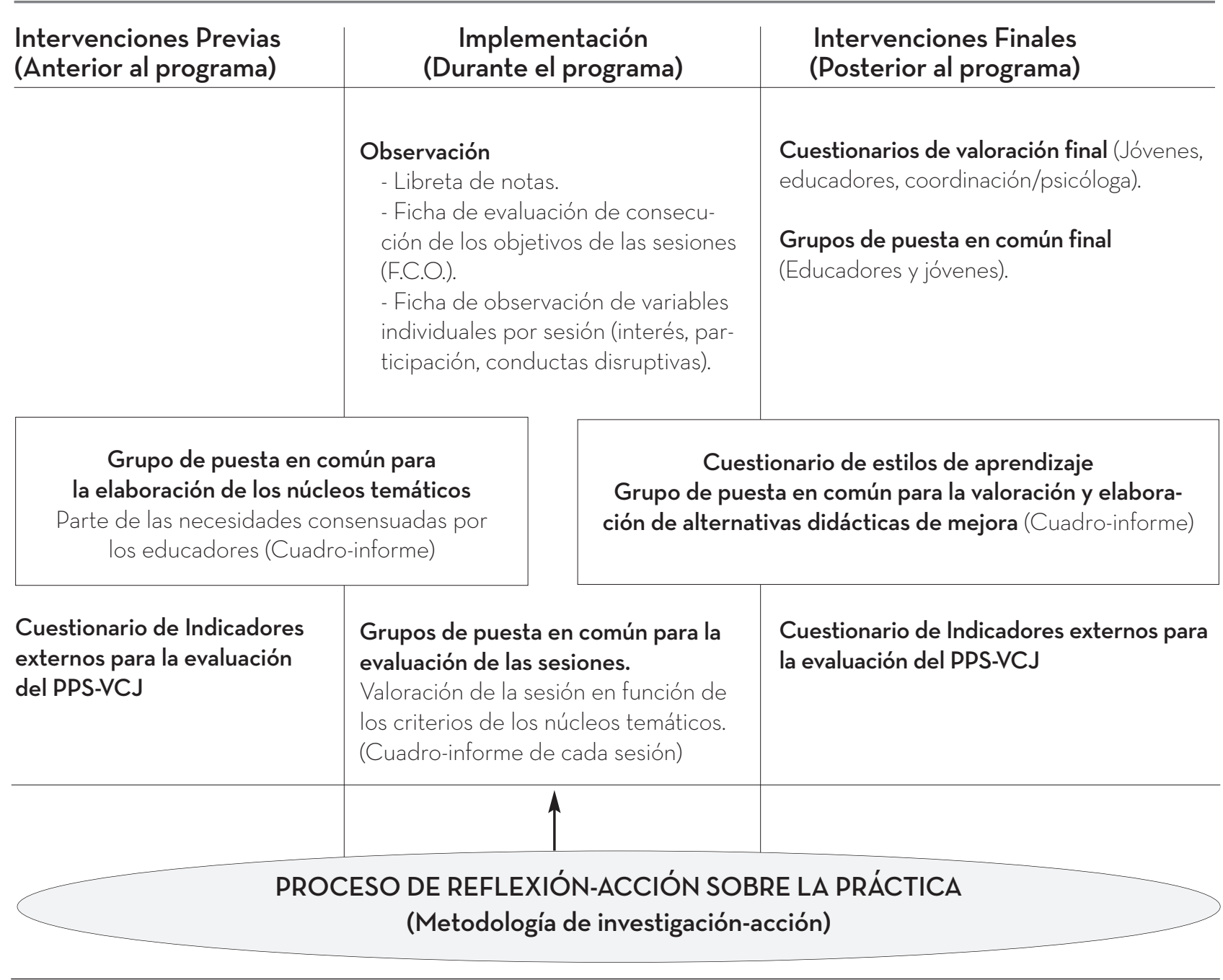


Table 1. Moments and methodological strategies of assessment

\section{PREVIOUS INTERVENTIONS IMPLEMENTATION FINAL INTERVENTIONS (Before the program) (During the program) (After the program)}

\begin{abstract}
Observation
Notebooks.

Assessment lists for evaluating the accomplishment of the sessions' objectives (F.C.O.).

Observation list of individual variables for each session (interest, participation, disruptive conducts).
\end{abstract}

Final Assessment Sampling (Adolescents, educators, coordination/psychologist)

Final Common Pooling Group

(Educators and adolescents)

\section{Common Pooling Group for Elaboration wit- hin Thematic Centers \\ Start from the thematic concepts agreed between the educators (Group Report)}

\section{Leaning Styles Sampling}

Common Pooling Group for assessment and elaboration of educational improvement proposals (Group Report)
External Indicators Sampling for evaluating PTP-SVY.
Common Pooling Groups for Session Evaluation

Session evaluation in accordance to criteria decided in the thematic concepts. (Group Report of each session).
External Indicators Sampling for evaluating PTP-SVY.

$\uparrow$

PROCESS OF REFLECTION-ACTION ABOUT THE PRACTICE (Metodology of active investigation)

informaciones recogidas así como a la adaptación y planificación de las sesiones. A través de la Investigación-Acción, los educadores pueden reflexionar sobre su práctica diaria y, junto con los internos, analizar las propuestas de trabajo, con el fin de buscar soluciones conjuntas y tomar decisiones (Pérez de Guzmán, Amador y Vargas, 2011). A su vez esta reflexión sobre la práctica se enmarca en un proceso de evaluación de programas que toma como referencia el modelo CIPP (Stufflebeam y Shinkfield, 2005).

Para la evaluación se han seguido diferentes momentos y estrategias metodológicas, que se describen en la Tabla 1. Exponemos a continuación las técnicas e instrumentos de recogida de información utilizados. the data and information gathered as well as the adaptation and planning of sessions. Through active research, teachers can reflect on their daily practice and, along with the inmates, analyze the work proposals in order to search for collective solutions and decisions (Perez de Guzman Amador and Vargas, 2011). Also, this reflection on practice is part of a process of evaluating programs based on the CIPP model (Stufflebeam and Shinkfield, 2005).

The evaluation followed different periods and methodological strategies, as described in Table 1. We describe subsequently the techniques and instruments used to collect information. 
1.3.1. Instrumentos utilizados por los educadores para la observación realizada durante el programa:

- Libreta de notas, permite al educador-investigador completar y contrastar la información obtenida.

- Ficha de evaluación de consecución de objetivos de las sesiones (F.C.O.) y Ficha de observación de las variables individuales por sesión (interés, participación y conductas disruptivas).

La finalidad de estas dos fichas es servir de registro de datos cuantitativos y cualitativos de las variables indicadoras del éxito de las sesiones (consecución de objetivos, interés, participación y conductas disruptivas), datos orientados a valorar la influencia de las propuestas didácticas desarrolladas en las sesiones implementadas. Estas dos fichas son una adaptación de las diseñadas "ad hoc" por los autores del programa (Alba et al., 2006).

\subsubsection{Cuestionarios.}

Constan de una parte cuantitativa y otra cualitativa (elaborados por el equipo de investigación).

Cuestionario de Indicadores Externos para la evaluación del PPS-VCJ (dirigido a jóvenes, educadores y evaluadores externos -coordinación y psicóloga-). Instrumento elaborado ad hoc por los autores del Programa del Pensamiento Prosocial-VCJ (Alba et al., 2005) para su evaluación, cuya finalidad es valorar los posibles cambios provocados tras la aplicación del programa (efectividad).

Cuestionario de valoración final. Su finalidad es ofrecer un espacio para explorar el grado de satisfacción y recoger la opinión final de los participantes (jóvenes, educadores y evaluadores externos -coordinación y psicóloga-).

Cuestionario de Estilos de Aprendizaje para educadores e informantes externos (coordinación y psicóloga). Se plantea como un instrumento de reflexión individual. Comienza repasando una serie de ítems sobre distintos estilos de aprendizaje que tienen como finalidad explorar las estrategias con las que nuestro colectivo de jóvenes suele enfrentarse al aprendizaje. Tras estos ítems, se proponen dos preguntas abiertas orientadas a definir el estilo de aprendizaje dominante que sirva de referencia a la elaboración de propuestas didácticas de mejora.
1.3.1. Instruments used by educators for observation during the program:

- Notepads, allowing educator-researchers to complete and contrast obtained information. - List of objectives achieved in evaluation sessions (FCO) and an observation list of individual variables for each session (interest, involvement and disruptive behavior).

The purpose of these two lists is to register both quantitative and qualitative data on the variables which indicate satisfying results during the sessions (achievement of objectives, interest, participation and disruptive behavior) and are oriented at valuing the influence of the educational proposals developed in these sessions. Both lists are adapted from "ad hoc" lists designed by the authors of the program (Alba et al., 2006).

\subsubsection{Samplings}

The samplings consist of two parts, quantitative and qualitative, respectively (developed by the research team).

External Indicator Samplings for the assessment of PPS-VCJ (for adolescents, educators and external evaluators - coordinators and psychologist). Instrument developed ad hoc by the authors of Pro-social Thinking Program-VCJ (Alba et al., 2005) for evaluation aimed to assess the possible changes caused after program implementation (effectiveness).

Final Assessment Sampling. Its purpose is to provide space to explore the degree of satisfaction and collect the final opinion of the participants (youth, educators and external evaluators - coordination and psychologist).

Learning Styles Sampling for educators and external informants (coordination and psychologist). It is proposed as a tool for individual reflection. First, it reviews a series of items on different learning styles that are intended to explore the strategies with which our young people often face collective learning. Then, it proposed two open questions aimed at defining the dominant learning style that will serve as a reference for the improvement of educational proposals. 
Estas reuniones, que hemos denominado Grupos de Puesta en Común, estarían a caballo entre el "grupo central» (McKillip, 1989; Pérez-Campanero, 1991), orientado al reconocimiento y diagnóstico de necesidades y problemas, y el "grupo de discusión» (Pérez-Campanero, 1991), encaminado especialmente a la toma de decisiones, aunque también pueda ser utilizado como técnica de diagnóstico.

Con esta puesta en común se busca una reflexión conjunta eficiente y funcional, dinamizada en nuestro caso por el educador-investigador, el cual presenta interrogantes y recoge ideas clave de la discusión, sintetizándolas para lanzarlas otra vez al grupo hasta que después de distintas matizaciones puedan ser asumidas por todo el grupo.

Los grupos de puesta en común (G.P.C.) son un instrumento de trabajo habitual durante toda la investigación. Hay cuatro bloques de especial transcendida que exponemos a continuación:

- G.P.C. para la elaboración de los núcleos temáticos. Orientados a que los educadores definiesen los núcleos temáticos (metacategorías) que permitiesen centrar la observación y el análisis sobre la intervención didáctica.

- G.P.C. para la evaluación de las sesiones. Probablemente este sea uno de los espacios más importantes de toda la investigación, ya que gracias a él se fundamentan muchas de las conclusiones y propuestas de mejora planteadas.

Antes de implementar cada una de las sesiones del programa se realiza una reunión de trabajo. En ellas el grupo de educadores observadores participantes, junto al educador investigador, valora los resultados obtenidos en la sesión pasada y negocia la información a incorporar en el cuadro-informe de núcleos temáticos de cada una de las sesiones. Una vez consensuado el cuadro-informe se podrá pasar a elaborar y adaptar la siguiente sesión del programa que se va a implementar

- G.P.C. para la valoración y elaboración de alternativas didácticas de mejora (para educadores). Parte de los resultados del cuestionario de estilos de aprendizaje como soporte para negociar y consensuar la elaboración de un conjunto de bases didácticas sencillas que ayuden a mejorar la aceptación y el rendimiento de las se-

\subsubsection{Groups of reflection and decision making}

These meetings, which we called Pooling Groups, would be somewhere between the "core group' (McKillip, 1989, Perez-Ringer, 1991), oriented to help recognize and appoint needs and problems, and the "discussion group" (PérezRinger, 1991), especially directed to decision making, but which also can be used as a diagnostic technique.

Therefore, we seek for an efficient, functional and sharing joint reflection, motivated in our case by the teacher-researcher, which raises questions and collects key ideas brought by the discussion, synthesizing them to deliver them back to the group, until the distinct capacities may be assumed by the entire group.

The common pooling groups (CPG) are a common working tool used throughout the investigation. It embraces four block of transcendent nature set forth below:

- C.P.G. for the development of the thematic. Oriented towards educators for defining the detailed thematic (metacategories) that permit focusing on observing and analyzing the educational intervention.

- C.P.G. for evaluation of the sessions. This is probably one of the most important parts of the research, and thanks to it many conclusions are made and suggestions for improvement are appointed.

Before implementing each of the sessions of the program work meeting are performed. In them, the group of observing-participating educators, along with the educator-researcher, assess the results obtained in the last session and discuss what information should be included in the thematic group reports from each sessions. Once there is agreement on the report, they may go on to develop and adapt the next session of the program.

- C.P.G. for the assessment and development of educational alternatives for improvements (for educators).

It embraces the results of the learning style sampling as a support for discussion and agreement on the development of a set of basic educational ele-

[ 158 ] MARÍA VIOLETA ÁLVAREZ FERNÁNDEZ, VÍCTOR RAÚL PINTADO REY Y JOSÉ LUIS SAN FABIÁN MAROTO SIPS - PEDAGOGIA SOCIAL. REVISTA INTERUNIVERSITARIA [1139-1723 (2014) 23, 151-172] TERCERA ÉPOCA 
siones y programas socioeducativos. Las alternativas de mejora se presentarán como hipótesis de acción facilitadoras del aprendizaje, organizadas en las metacategorías (núcleos temáticos) definidas al principio del proceso.

- G.P.C. final para educadores. Se pretende conseguir una valoración y reflexión global colectiva con objeto de establecer las conclusiones y propuestas de mejora finales.

- G.P.C. final para internos. El grupo está coordinado y dinamizado por el educador-investigador, con la asistencia de uno o dos educadores observadores participantes, teniendo como esquema de trabajo una serie de preguntas sencillas que den pie a la discusión entre los jóvenes participantes. Se orienta a realizar una valoración colectiva de las acciones desarrolladas, así como a definir las posibles propuestas de mejora que podrían incorporarse.

Aunque la reflexión-acción está presente en la mayoría de los momentos y procesos de la investigación, toma especial relevancia el desarrollo y valoración de las sesiones de trabajo. A continuación presentamos los pasos que se han seguido:

- Planificación. A través de los Grupos de puesta en común para la evaluación de las sesiones. Se intenta dar respuesta a las características de los jóvenes y del contexto. Se respeta, en líneas generales, los objetivos, contenidos y la distribución acumulativa de sesiones que plantea el PPS-VCJ pero se adaptan e incorporan propuestas didácticas (actividades, recursos, técnicas, etc.).

- Desarrollo de la sesión. Implementamos la sesión agudizando la capacidad de observación para poder recoger al final de la misma los datos e informaciones relacionadas con las variables indicadoras del éxito (consecución de objetivos, interés y participación, conductas disruptivas) y las metacategorías de análisis didáctico (núcleos temáticos).

- Recogida de información. Una vez finalizada la sesión, los educadores observadores participantes cumplimentan las dos fichas de registro y el educador-investigador escribe en su libreta de notas sus impresiones personales y reflexiones ments that help to improve the acceptance and performance of the sessions and social and educational programs. The improvement alternatives are presented as hypotheses of action learning facilitators, organized in the meta-categories (thematic) defined at the beginning of the process.

- Final C.P.G.. for educators. It aims to achieve a comprehensive evaluation and global reflection to establish the conclusions and final improvement proposals.

- Final C.P.G. for adolescents

The group is coordinated and mediated by the teacher-researcher, with the assistance of one or two observing-participating educators, working with a series of simple questions that invite discussion among the young participants. It aims to make a collective assessment of the actions and to define potential areas of improvement that may be incorporated.

Although the reflection-action is present in most of the moments and processes of research, the process of development and valuing the work sessions is of main importance. For this, we have followed certain steps:

- Planning. Done through the sharing groups for assessment of the sessions, it attempts to answer the characteristics of the adolescents and their context. In general, the objectives, contents and the cumulative distribution of sessions posed PTP-SVY are maintained, but adaptions are made and educational proposals incorporated (activities, resources, techniques, etc..).

- Development of the session. We implement the session refining observation skills in order to pick at the end of the sessions data and information related to the success indicating variables (achievement of objectives, interest and participation, disruptive behavior) and didactic analytic meta-categories (themes).

- Collection of information. After the session, the observing-participating educators complete two registration lists and the educatorresearcher writes in his notebook personal impressions and reflections derived from in- 
Tabla 2. Finalidades y fuentes de las estrategias de evaluación

\section{Observación: Registros}

\begin{tabular}{|c|c|c|c|}
\hline Libreta de notas. & $\begin{array}{l}\text { 口 Recoger información sobre situaciones reflexiones, discre- } \\
\text { pancias, decisiones y valoraciones que surjan durante el pro- } \\
\text { ceso. } \\
\text { 口 Permitir al educador-investigador completar y contrastar la } \\
\text { información que le aportan los educadores/as observadores } \\
\text { participantes. }\end{array}$ & & $x$ \\
\hline $\begin{array}{l}\text { Ficha de evaluación grupal de consecución de los } \\
\text { objetivos de las sesiones (F.C.O.). }\end{array}$ & \multirow{2}{*}{$\begin{array}{l}\text { 口 Registrar información sobre las cuatro variables indicadoras } \\
\text { del éxito de los aprendizajes («consecución de objetivos», «in- } \\
\text { terés», «participación»y «conductas disruptivas»), con la inten- } \\
\text { ción de poder valorar la influencia de las propuestas didácti- } \\
\text { cas planteadas en las sesiones. }\end{array}$} & $x$ & \\
\hline $\begin{array}{l}\text { Ficha de observación de variables individuales por } \\
\text { sesión (interés, participación, conductas disruptivas). }\end{array}$ & & $x$ & \\
\hline
\end{tabular}

\section{Grupos de Puesta en Común (G.P.C.)}

G.P.C. para la elaboración de los núcleos temáticos (Cuadro-informe).

G.P.C. para la evaluación de las sesiones (Cuadro-Informe de cada sesión).

G.P.C. para la valoración y elaboración de alternativas didácticas de mejora (Cuadro-informe) G.P.C. final o del impacto final (Cuadro-informe). Se dirige a educadores/as y a jóvenes.
- Definir las metacategorías (núcleos temáticos) que nos permitan centrar la observación y el análisis sobre la intervención didáctica.

- Valorar los resultados obtenidos en la sesión desarrollada y adaptar y elaborar la siguiente.

- Consensuar un conjunto de bases didácticas de referencia en intervención socioeducativa.

口 Proporcionar una valoración y reflexión colectiva del impacto final de la investigación.

\section{Cuestionarios}

Cuestionario de Indicadores Externos -pretest/postest- (se presenta en forma de entrevista a los/as jóvenes).

Cuestionario de estilos de aprendizaje.

Cuestionario de valoración final (tres instrumentos adaptados).

Proceso de reflexión-acción sobre la práctica

(Metodología de investigación-acción)
- Completar la descripción de las características de la muestra en el ámbito judicial.

口 Evaluar los posibles cambios provocados tras la aplicación del programa (efectividad).

- Estimular y recopilar las características relacionadas con las estrategias dominantes que más utiliza nuestro colectivo de jóvenes.

- Servir de referencia a la elaboración de propuestas o bases didácticas de mejora.

口 Explorar el grado de satisfacción y recoger la opinión final de los participantes -programa-

口 Provocar la reflexión sobre los datos e informaciones recogidas con objeto de ir ajustando y mejorando nuestra intervención.

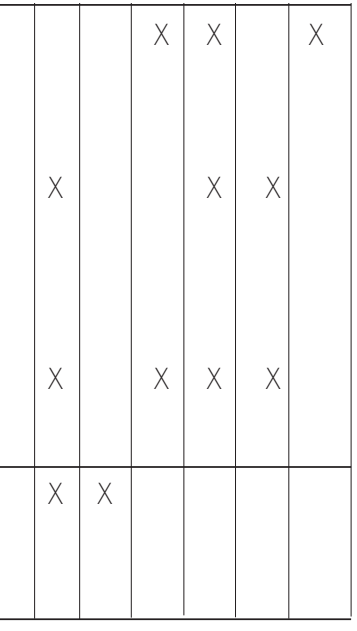

[ 160 ] MARÍA VIOLETA ÁLVAREZ FERNÁNDEZ, VÍCTOR RAÚL PINTADO REY Y JOSÉ LUIS SAN FABIÁN MAROTO SIPS - PEDAGOGIA SOCIAL. REVISTA INTERUNIVERSITARIA [1139-1723 (2014) 23, 151-172] TERCERA ÉPOCA 
Table 2. Objectives and strategic instruments of evaluation

Strategy What is intended? Informers

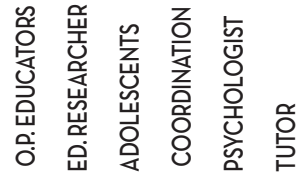

\section{Observación: Registros}

\begin{tabular}{|c|c|c|c|}
\hline Notebook. & $\begin{array}{l}\text { Collect information about situations, reflexions, discrepan- } \\
\text { cies, decisions and evaluations that appear during the pro- } \\
\text { cess. } \\
\text { a Allow the educator-researcher to complete and compare } \\
\text { the information brought by the observer-participant educa- } \\
\text { tors. }\end{array}$ & & \\
\hline $\begin{array}{l}\text { Group evaluation list of objectives accomplished } \\
\text { during the sessions, (G.O.S.) }\end{array}$ & \multirow{2}{*}{$\begin{array}{l}\text { 口 Register information about the four variables that indicate } \\
\text { learning accomplishments - "accomplishments of objectives", } \\
\text { "interest", "participation", and "disruptive conducts" - with the } \\
\text { intention to evaluate the influence of the eucational proposi- } \\
\text { tions used in the sessions. }\end{array}$} & & \\
\hline $\begin{array}{l}\text { Observation list of individual variables for each ses- } \\
\text { sion (interest,participation, disruptive conducts). }\end{array}$ & & & \\
\hline
\end{tabular}

\section{Common Pooling Group (C.P.G.)}

C.P.G. for elaborating the basic themes

(Group Report)

C.P.G. for evaluating the session (Group Report of each session)

.C.P.G. for evaluating and elaborating educational alternatives for improvement (Group Report)

.Final or Impact C.P.G. Directed to the educator and the adolescents. (Group Report)
口 Define the metacategories (thematic concepts) that allow us to focus on the observation and analysis of the educational intervention.

$\square$ Evaluate the results obtained in the sesión and adapt and elaborate the next one.

- Agree on a scheme of basic elements for social-educational intervention.

口 Promote a collective evaluation and reflection on the final impact of the intervention.

\section{Samplings}

-External Indicators Sampling - pretest/post-test applied as enterview with the adolescents

-Learninig Styles Sampling.

.Final evaluation sampling (three adapted instruments)

Process of reflection-action about the practice (Methodology of active investigation) $\square$ Describe the sample's carachteristics in the judicial spectrum.

$\square$ Evaluate posible changes brough by the application of the program.

$\square$ Stimulate and reproduce the carachteristics related to the stratagies most used by our adolescents.

- Serve as reference for the elaboration of the educational foundings or propositions for improvement.

口 Identify the degree of satisfation and collect the final opinión of all participants in the program.

口 Stimulate the reflection on all the information collected with means to promote the necessary ajustments to improve our intervention.
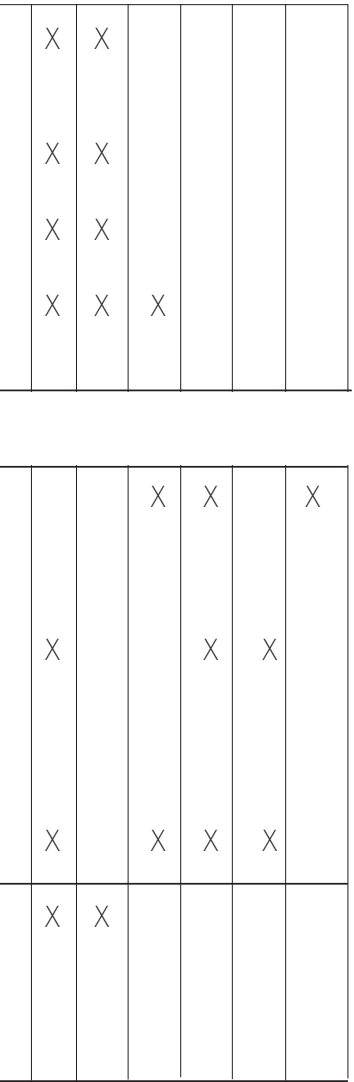
derivadas de las reuniones informales de valoración efectuadas al salir de la sala.

- Reflexión. Con todos los datos e informaciones recogidas se valora la sesión desarrollada, teniendo como guía para el análisis las metacategorías o núcleos temáticos definidos con anterioridad en el grupo de puesta en común. Esta secuencia finaliza con la negociación y el consenso que nos permita cumplimentar el cuadro-informe de la sesión.

Cada una de las estrategias de recogida de información está asociada a unos propósitos y a unos informantes, que se resumen en la Tabla 2.

\subsection{Análisis de la información y rigor científico}

Ante el reducido tamaño de los colectivos implicados en el estudio, los análisis cuantitativos se realizaron a través de estadísticos descriptivos (medias y porcentajes), que se presentaron en tablas y gráficos que buscaban organizar los resultados y facilitar su interpretación.

En relación a la información cualitativa se aplicaron diferentes propuestas de análisis de contenido: exploración, lectura, síntesis, organización de ideas y generación de constructos teóricos que van asignando sentido y significado a la información recogida.

Como criterios y procedimientos de rigor científico destacamos la abundancia de datos, las pistas de revisión, la triangulación y la cristalización; entendiendo por cristalización el rigor fruto de la negociación y el consenso, conseguido principalmente en los denominados grupos de puesta en común (Richardson, 1997). Este criterio insiste en la conveniencia de utilizar criterios democráticos a la hora de diseñar, implementar, evaluar y plantear mecanismos orientados a la mejora de nuestra intervención social.

\section{Resultados}

Presentamos a continuación los resultados más significativos obtenidos de los diferentes instrumentos de recogida de información señalados con anterioridad. formal evaluation meetings done when leaving the room.

- Reflection. With all the data and information gathered the session is evaluated, guided by the meta-categories for analysis or thematic previously defined in the pooling group. This sequence ends with the discussion and compromise that allows us to complete the session report.

Each one of the strategies for collecting information is associated to a purpose and an informer, summarized in Table 2.

\subsection{Data analysis and scientific rigor}

Given the small size of the groups involved in this study, quantitative analyzes were performed by descriptive statistics (means and percentages), presented in tables and graphs which sought to organize the results and facilitate interpretation.

Regarding the qualitative information, different analytical approaches were made towards the subject: exploring, reading, synthesis, organization of ideas and generation of theoretical constructs that make sense and meaning out of the gathered information.

As criteria for scientific rigor and procedure, we emphasize the enormous amount of data, review clues, triangulation and crystallization, crystallization which should be understood as the rigor that results from discussion and consensus, achieved mainly in the so-called pooling groups (Richardson, 1997). This approach emphasizes the convenience of using democratic criteria to the design, implement, evaluate and propose mechanisms to improve our social intervention.

\section{Results}

Next, we present the most significant results obtained with the application of different instruments of data collection indicated above.

[ 162 ] MARÍA VIOLETA ÁLVAREZ FERNÁNDEZ, VÍCTOR RAÚL PINTADO REY Y JOSÉ LUIS SAN FABIÁN MAROTO SIPS - PEDAGOGIA SOCIAL. REVISTA INTERUNIVERSITARIA [1139-1723 (2014) 23, 151-172] TERCERA ÉPOCA 


\subsection{Resultados de las variables indicadoras del éxito de las sesiones (educadores del equipo de investigación)}

Las variables, que hemos querido denominar indicadoras del éxito de las sesiones (consecución de objetivos, interés, participación y conductas disruptivas), obtienen puntuaciones parecidas, observándose gráficas que describen líneas semejantes. Se aprecia también una serie de sesiones donde se obtienen puntuaciones muy positivas (sesión no 4, 11, 13 y 6), otras donde coinciden las puntuaciones más negativas (sesión no 7, 10 y 8) y un último bloque (sesiones no 1, 2, 3, 5, 9, 12) donde los resultados, en líneas generales, podrían considerarse medios.

La información cualitativa de las fichas de registro y las libretas de notas nos permite observar que en las sesiones con mejores puntuaciones en estas variables se implementaron tareas y actividades que les resultaron atractivas y estuvieron adaptadas a las características de los jóvenes (evolutivas, emocionales, culturales, etc.). En cambio, las sesiones con puntuaciones más bajas, parecen más alejadas de su realidad y características, planteando tareas que les exigen un razonamiento excesivamente abstracto y estructurado. Finalmente, en las sesiones de resultados medios parece observarse cierta heterogeneidad de tareas y actividades, sin apreciarse con tanta claridad posibles relaciones.

\subsection{Resultados de los grupos de puesta en común para la categorización y la evaluación de las se- siones (educadores del equipo de investigación)}

Las metacategorías o grupos temáticos para estructurar y sistematizar el análisis de la intervención didáctica fueron las siguientes:

- Recursos metodológicos: repertorio de instrumentos y métodos pedagógicos utilizados.

- Acomodación a las características de los jóvenes: nivel de adaptación de las actividades a los internos con objeto de que sean significativas (partir de sus conocimientos previos) y de interés para ellos, pudiendo ser capaces de apreciar su utilidad con objeto de fomentar la participación e implicación en unas tareas que les resulten atractivas y cercanas.

- Contexto de aprendizaje: entorno de inter-

\subsection{Results of the indicator variables for the success of the sessions (teachers of the research team).}

The variables that we denominate indicators of the success accomplishments in the sessions (achievement of objectives, interest, participation and disruptive behaviors) obtain similar scores, as shown in graphs depicting similar lines. Also it can be said that some of sessions score very positively (session \# 4, 11, 13 and 6), while others present more negative scores (session \# 7,10 and 8) and in one block (sessions 1, 2, 3, 5, 9, 12) where the results, in general, may be considered of medium kind.

Qualitative information from the registration lists and notebooks allows us to observe that in the sessions with better scores the tasks and activities implemented were attractive and well adapted to the characteristics of adolescents (developmental, emotional, cultural characteristics, etc.). On the other hand, the sessions with lower scores, seem more distant from their reality and characteristics, establishing tasks that require excessive abstract and structured reasoning. Finally, in the sessions with medium results, there seems to be certain heterogeneity of tasks and activities, in which possible relations are not so clearly identifiable.

\subsection{Results of pooling groups for categorization and evaluation sessions (teachers of the research team)}

The meta-categories or thematic groups used to structure and systematize the analysis of the educational intervention were:

- Methodological resources: repertoire of pedagogical tools and methods.

- Adaptation to the characteristics of the adolescents: adaptation level internee's activities so to make them meaningful (with regard to previous knowledge) and of interest to them and making it possible to appreciate its utility in encouraging their participation and involve- 
vención relacionado con la organización de los espacios (único/variados), la estructuración del tiempo (flexible y cambiante), los distintos agrupamientos (individual, pequeño grupo -parejas-, grupo completo) y acompañamientos individuales.

- Clima de trabajo: ambiente propicio para la asimilación de saberes y la participación activa de los educandos. Para ello será importante disminuir el número de conductas disruptivas que obstaculicen la marcha normal de las sesiones dificultando la atención, el aprendizaje y las relaciones interpersonales.

Tras el proceso de reflexión-acción y la cumplimentación de los 13 cuadros-informe de las sesiones, destacamos los siguientes resultados obtenidos:

En las sesiones con mejores puntuaciones en las variables indicadoras del éxito, las propuestas didácticas utilizadas son:

- recursos metodológicos activos, con métodos dinámicos y manipulativos.

- tareas y actividades contextualizadas, que parten de sus conocimientos previos, sus intereses y experiencias.

- contextos de aprendizaje variados y flexibles en relación a los espacios, los tiempos y el tipo de agrupamiento.

- clima de participación activo y ordenado.

Por el contrario, en las sesiones con las puntuaciones más bajas en las variables indicadoras del éxito, las propuestas didácticas utilizadas son:

- recursos metodológicos mecánicos y expositivos, con estructuras de contenidos complejas y abstractas.

- tareas y actividades estandarizadas, sin contextualizar y poco significativas.

- espacios y tiempos estáticos y continuos.

- no se fomenta la participación, se recurre especialmente a la exposición magistral y a la lectura de textos para responder a unas preguntas de forma individual. ment in tasks that they find attractive and close to their reality.

- Learning context: intervention environment related to the organization of spaces (unique / varied), time structure (flexible and changeable), different groupings (individual, small group-pairs-Whole group) and individual assistance.

- Work Atmosphere: propitious environment for the assimilation of knowledge and active participation of learners. To achieve this, it is important to reduce the number of disruptive behaviors that impede the normal operation of the sessions, making it difficult to maintain attention, learn and develop interpersonal relationships.

After reflection-action process and the accomplishment of the 13 frame-report sessions, results include:

In sessions with higher scores in the variables of success indicators, the educational proposals were considered:

- Active methodological resources, with dynamic and maneuverable methods.

- Contextualized tasks and activities that are based on the adolescents prior knowledge, interests and experiences.

- Flexible and diverse learning contexts in regard to space, time and forms of grouping.

- Active, participative, and organized atmosphere.

Still, in the meetings with the lowest scores on the indicator variables of success, the educational proposals used were diagnosed as:

- Mechanical and expositive methodological resources, with complex and abstract structures.

- Standardized tasks and activities without context and meaning.

- Static and continuous space/time relation.

- Participation is not encouraged, rather using professor-like exposures and text reading in order to next answer questions individually.

[ 164 ] MARÍA VIOLETA ÁLVAREZ FERNÁNDEZ, VíCTOR RAÚL PINTADO REY Y JOSÉ LUIS SAN FABIÁN MAROTO SIPS - PEDAGOGIA SOCIAL. REVISTA INTERUNIVERSITARIA [1139-1723 (2014) 23, 151-172] TERCERA ÉPOCA 


\subsection{Resultados del cuestionario de estilos de aprendizaje (educadores del equipo de investi- gación, coordinación y psicóloga)}

Como síntesis de los resultados obtenidos adjuntamos las características más significativas que definen el estilo de aprendizaje dominante de nuestro grupo de jóvenes:

- Niveles bajos de motivación, implicación y capacidad de esfuerzo.

- Escasos recursos para enfrentarse a las actividades socio-educativas (especialmente las de corte cognitivo).

- Dificultades para mantener la atención durante un tiempo prolongado (impulsivos).

- En el aprendizaje de contenidos, prefieren que sean de su interés (cercanos a su contexto sociocultural, a sus vivencias, recuerdos y emociones); les resultan más atractivas las actividades dinámicas, prácticas y variadas; les dan seguridad las pautas de trabajo bien marcadas, claras y precisas; se centran en aspectos concretos vinculados con vivencias personales y situaciones emocionales, que actúan como andamiaje para conseguir conocimientos, reflexiones y pensamientos más abstractos.

\subsection{Resultados del grupo de puesta en común para la valoración y elaboración de alternativas didácticas de mejora (educadores del equipo de investigación)}

Presentamos a continuación un conjunto de criterios didácticos que contribuyen a mejorar el éxito de los programas de competencia social en nuestro grupo de jóvenes.

- Recursos metodológicos: dirigir nuestra intervención hacia modelos didácticos activos y proponer tareas que permitan al joven actuar, hacer, decir, pensar, etc.

- Acomodación a las características de los jóvenes: partir de su contexto de referencia y de sus características personales; ofrecer propuestas que les resulten atractivas y motivadoras (significativas, funcionales, útiles, que partan de sus vivencias -recuerdos, emociones, etc.-) y transmitir nuestra motivación, nuestro esfuerzo e implicación (hacerles ver que nos preocupamos por ellos).
2.3. Results of the learning styles sampling (teachers of the research team, coordination and psychologist).

As a synthesis of the results, we systematized the most significant features that define the dominant learning style of our youth group:

- Low levels of motivation, involvement and effort capacity.

- Scarce resources to meet socio-educational activities (especially of a cognitive type).

- Difficulty maintaining attention for a long time (impulsive).

- Regarding the subjects, they prefer them to match their interests (related to their sociocultural context, their experiences, memories and emotions); they are more attracted to dynamic, practical and diversified activities; clear, precise and delimitated work guidelines give them security; their focus centers on concrete aspects related to personal experiences and emotional situations that act as platform for structuring knowledge, ideas and abstract thoughts.

2.4. Results of the pooling group for the assessment and development of educational alternatives for improvement (educators from the research team)

We now present a set of educational standards that help improve the accomplishments of social competence programs in our youth group.

- Methodological resources: direct our intervention towards active teaching models and propose learning tasks that allow the adolescents to act, do, speak, think, etc.

- Adaptation to the adolescents' characteristics: according to their frame of reference and personal characteristics; offer approaches that are attractive and motivating to them (significant, functional, useful, stemming from their experiences, memories, emotions, etc.) and transmit our motivation, our effort and involvement (to show them that we care about them). 
Tabla 3. Comparación de los resultados sobre la efectividad del programa con otras experiencias similares

\begin{tabular}{|c|c|c|c|}
\hline Programa PPS-VCJ & MUESTRA/CONTEXTO & EVALUACIÓN & RESULTADOS \\
\hline LLEIDA & $\begin{array}{l}\text { Duración: } 12 \text { sesiones } \\
\text { No sujetos: } 6 \\
\text { Edad: } 15-18 \\
\text { Sexo: } V \\
\text { Menores en medio abierto }\end{array}$ & $\begin{array}{l}\text { Nivel de riesgo (YLS) BAS-3. } \\
\text { Batería de Socialización IAC. } \\
\text { Inventario de Adaptación de } \\
\text { Conductas AECS. Actitudes y } \\
\text { estrategias cognitivas sociales. } \\
\text { Evaluación sumativa/proceso }\end{array}$ & $\begin{array}{l}\text { Mejoras en la capacidad reflexiva, en la } \\
\text { seguridad y firmeza en la interacción. } \\
\text { Mejoras en el comportamiento y mayor } \\
\text { participación. } \\
\text { Asistencia regular. }\end{array}$ \\
\hline $\begin{array}{l}\text { CENTRO } \\
\text { S.V. FERRER-GODELLA- }\end{array}$ & $\begin{array}{l}\text { Duración: } 13 \\
\text {.No sujetos: } 13 \\
\text {-Edad: } 15-17 \\
\text { Sexo: } V \\
\text { Menores en régimen ce- } \\
\text { rrado y emiabierto. }\end{array}$ & $\begin{array}{l}\text { I.G.I.J. y Cuestionario de indi- } \\
\text { cadores externos para la eva- } \\
\text { luación del PPS.VCJ. }\end{array}$ & $\begin{array}{l}\text { Mejoras en la capacidad de reconocer } \\
\text { cuándo se están metiendo en proble- } \\
\text { mas, siendo capaces de pedir ayuda a } \\
\text { los demás, verbalizar sus emociones y } \\
\text { no enfadarse con tanta facilidad como } \\
\text { al inicio de la intervención. }\end{array}$ \\
\hline $\begin{array}{l}\text { CASA JUVENIL DE } \\
\text { SOGRANDIO -OVIEDO- }\end{array}$ & $\begin{array}{l}\text { Duración: } \\
13 \text { sesiones } \\
\text { No sujetos: } 9 \\
\text {-Edad: } 14-20 \\
\text { Sexo: } \text { Vy M } \\
\text { Menores en } \\
\text { régimen de } \\
\text { internamiento semiabierto } \\
\text { y cerrado. }\end{array}$ & $\begin{array}{l}\text { Cuestionario de indicadores } \\
\text { externos -pretest-postest- } \\
\text { (Alba, Garrido y López, 2005). } \\
\text { Cuestionario de valoración fi- } \\
\text { nal (nivel de satisfacción). } \\
\text { Grupo de puesta en común fi- } \\
\text { nal. }\end{array}$ & $\begin{array}{l}\text { En el ámbito personal se aprecia cierta } \\
\text { influencia positiva del PPS-VCJ, con } \\
\text { cambios manifiestos, especialmente en } \\
\text { algunos espacios relacionados con: } \\
\text { - la dimensión emocional: verbaliza- } \\
\text { ción de emociones. } \\
\text { - la resolución de problemas: capaci- } \\
\text { dad de demandar ayuda ante los } \\
\text { problemas y reconocer y plantearse } \\
\text { la necesidad de cambio. } \\
\text { - el autocontrol / tolerancia a la frus- } \\
\text { tración: disminución de las reaccio- } \\
\text { nes agresivas, reducción de enfrenta- } \\
\text { mientos con la autoridad y mayor } \\
\text { capacidad para no enfadarse con } \\
\text { tanta facilidad. } \\
\text { Se observan también niveles de satis- } \\
\text { facción muy altos en jóvenes, educado- } \\
\text { res e informantes externos. }\end{array}$ \\
\hline
\end{tabular}

Fuente: Elaborado a partir de López y Garrido (2005, pp. 77-86).

- Contexto de aprendizaje: flexibilizar la organización (espacios, tiempos, agrupamientos).

- Clima de trabajo: crear un clima de seguridad y respeto (firmeza sosegada en las decisiones); realizar explicaciones claras, cortas y precisas; preparar las tareas con tiempo suficiente y buscar la participación activa y ordenada.

\subsection{Resultados sobre la eficacia del programa}

En relación a la valoración de la influencia del programa se aprecian estos cambios positivos:

- En cinco de los nueve jóvenes se observa un cambio positivo en el ítem "verbaliza sus emociones". - Cinco de los educandos que participaron en la investigación mejoran con respecto a los datos
- Learning context: promote flexible organization of space, time, and groups.

- Work Atmosphere: create an atmosphere of safety and respect (quiet firmness in decisions); explicate clearly, shortly and precisely; prepare assignments with sufficient time for realization and seek after active and orderly participation.

\subsection{Results on the effectiveness of the program}

Regarding the assessment of the impact of the program we note the following positive changes: - In five of the nine adolescents there was a positive change in the item "verbalizing your emotions." - Five of the students involved in the research improved regarding to their pre-test data in any

[ 166 ] MARÍA VIOLETA ÁLVAREZ FERNÁNDEZ, VÍCTOR RAÚL PINTADO REY Y JOSÉ LUIS SAN FABIÁN MAROTO SIPS - PEDAGOGIA SOCIAL. REVISTA INTERUNIVERSITARIA [1139-1723 (2014) 23, 151-172] TERCERA ÉPOCA 
Table 3. Comparación de los resultados sobre la efectividad del programa con otras experiencias similares

\begin{tabular}{|c|c|c|c|}
\hline PTP-SVY Program & SAMPLE/CONTEXT & EVALUATION & RESULTS \\
\hline LLEIDA & $\begin{array}{l}\text { Extension: } 12 \text { sessions } \\
\text { No of subjects: } 6 \\
\text { Ages: } 15-18 \\
\text { Sex: } M \\
\text { Underaged youth in parole } \\
\text { condition }\end{array}$ & $\begin{array}{l}\text { Risk level (YLS) BAS-3. Sociali- } \\
\text { zation Pile. IAC - Conduct } \\
\text { Adaptation Inventory. SCSA - } \\
\text { Social cognitive strategies and } \\
\text { actitudes. Procedural assess- } \\
\text { ment }\end{array}$ & $\begin{array}{l}\text { Improvement in capacity of reflection, } \\
\text { in security and steadiness during inte- } \\
\text { raction. } \\
\text { Improvement in behavior and more } \\
\text { participation. } \\
\text { Continuous assistence. }\end{array}$ \\
\hline $\begin{array}{l}\text { CENTRO } \\
\text { S.V. FERRER-GODELLA- }\end{array}$ & $\begin{array}{l}\text { Extension:13 } \\
\text {-Nosubjects:13 } \\
\text {-Ages: 15-17 } \\
\text { Sex: } \mathrm{M} \\
\text { Underaged youth in closed } \\
\text { and semi-open internment. }\end{array}$ & $\begin{array}{l}\text { I.G.I.-J. y External Indicators } \\
\text { Sampling for assessing PTP. } \\
\text { SVY }\end{array}$ & $\begin{array}{l}\text { Improvement in their capacity of recog- } \\
\text { nizing when they are getting into trou- } \\
\text { ble, being capable of asked others for } \\
\text { help, verbalize their emotions and not } \\
\text { irritate themselves so easily as in the } \\
\text { beginning of the intervention. }\end{array}$ \\
\hline $\begin{array}{l}\text { CASA JUVENIL DE SOGRANDIO } \\
\text {-OVIEDO- }\end{array}$ & $\begin{array}{l}\text { Extension: } 13 \text { sessions } \\
\text { No subjects: } 9 \\
\text { Ages: } 14-20 \\
\text { Sex: My F } \\
\text { Underaged youth in closed } \\
\text { and semi-open internment. }\end{array}$ & $\begin{array}{l}\text { External Indicators Sampling } \\
\text {-pretest/post-test (Alba, Ga- } \\
\text { rrido y López, 2005). } \\
\text { Final evaluation sampling (le- } \\
\text { vels of satisfaction). } \\
\text { Final Common Pooling Group. }\end{array}$ & $\begin{array}{l}\text { In personal matters a certain positive } \\
\text { influence of PTP-SVY can be noted } \\
\text { with profound changes, specially in as- } \\
\text { pects related to: } \\
\text {-The emotional dimensión: verbaliza- } \\
\text { tion of emotions. } \\
\text {-Problem solving: Capacity of asked } \\
\text { for help with problems, recognizing } \\
\text { and stipulating the need for change. } \\
\text {-Self-control/ tolerance with frustra- } \\
\text { tion. Decrease of agreesive reactions, } \\
\text { reduction of confrontation towards } \\
\text { authority and greater capacity of not } \\
\text { getting irritated so easily. } \\
\text { High levels of satisfation are also obser- } \\
\text { ved within the adolescents, educators } \\
\text { and external informers. }\end{array}$ \\
\hline
\end{tabular}

Source: Elaborated with reference to López y Garrido (2005, pp. 77-86).

del pretest en alguno de los ítems relacionados con "Autocontrol/Tolerancia a la frustración", apreciándose una disminución de las reacciones agresivas, los enfrentamientos con la autoridad y una mayor capacidad para no enfadarse con tanta facilidad.

- En cuatro de los nueve internos se produce un cambio positivo en algún ítem relacionado con "Resolución de problemas".

Estos resultados se consideran muy positivos teniendo en cuenta la compleja problemática social y personal del colectivo de jóvenes con los que trabajamos, así como el escaso periodo de tiempo en el que se concentra esta intervención (13 horas). De hecho, en comparación con otras experiencias se- of the items related to "self-control/tolerance to frustration", presenting a decrease in aggressive reactions, confrontations towards authority and greater ability in not getting angry so easily.

- In four of the nine inmates there was a positive change in any item related to "problem solving"

These results are considered very positive keeping in mind the complex social and personal problems of this group of adolescents whom we work, as well as the limited period of time in which this intervention was executed (13 hours). In fact, compared with other similar experiences of PPSVCJ, such as Lleida and S. Center V. Ferrer- 
mejantes del PPS-VCJ, como la de Lleida y la del Centro S. V. Ferrer -Godella- (López y Garrido, 2005), los resultados son parecidos (Tabla 3), destacando especialmente una mejora sustancial en su comportamiento (mayor autocontrol, disminución de conductas agresivas, etc.) y cambios positivos en estrategias vinculadas a la resolución de problemas.

\subsection{Resultados sobre la valoración final y el nivel de satisfacción}

Para la reflexión final se utilizaron dos instrumentos: el Cuestionario de Valoración final (de jóvenes, educadores e informantes externos -coordinación y psicóloga-) y el Grupo de puesta en común final (jóvenes y educadores).

Sintetizamos los resultados obtenidos y validados: - Los agentes implicados (jóvenes, educadores e informantes externos) manifiestan que las nuevas metodologías desarrolladas son: atractivas, útiles, interesantes, dinámicas, flexibles y están bien planificadas. Coinciden en destacar el positivo impacto que ha tenido la experiencia, confirmando así un nivel de satisfacción muy alto por parte de todos. - El proceso formativo de investigación-acción se considera un recurso apropiado para optimizar la práctica de los educadores sociales, tal como han mostrado otros estudios (e.g. Fernández Gutiérrez, 2003).

- La valoración del trabajo y la motivación de los jóvenes hacia estas nuevas dinámicas es alta, convirtiendo la propuesta socioeducativa en una experiencia capaz de reducir las reticencias de los jóvenes hacia los programas de corte socio-cognitivo (como el Programa de Pensamiento Prosocial). En este sentido, los jóvenes señalan que sería interesante tener más protagonismo a la hora de plantear temas de trabajo, así como más tiempos y espacios para verbalizar y analizar los problemas desde su propia óptica.

\section{Discusión y propuestas didácticas de mejora}

La investigación pone de relieve, en primer lugar, la importancia de conseguir un clima de compromiso profesional con la formación activa de los educadores y educadoras sociales, siendo los propios pro-
Godella-(Lopez and Garrido, 2005), the results are similar (Table 3), with a special emphasis on the substantial improvement in their behavior (higher self, decreased aggressive behavior, etc..) and positive changes in strategies related to the problem solving.

\subsection{Results on the final assessment and the level of satisfaction}

For the final reflection two instruments were used: the Final Assessment Sampling (youth, educators and external informants - coordination and psychologist) and the final pooling group end (youth and educators).

We synthesized the following validated results: - All parts involved (youth, educators and external informants) indicated that the new methodologies developed are: attractive, useful, interesting, dynamic, flexible and well planned. They agree in emphasizing the positive impact it had in the experience, thus confirming very high level of satisfaction for all.

- The formation process of active research is considered an appropriate resource to optimize the practice of social workers, as other studies have shown (Fernández Gutiérrez, 2003)

- The adolescents presented a high appreciation of work and motivation towards these new dynamics, making the proposed socio-educational experience capable of reducing the reluctance of adolescents towards programs of socio-cognitive nature (such as Pro-social Thinking Program). In this sense, the adolescents affirm that it would be interesting for them to have more prominence when working to raise issues and more time and space to verbalize and analyze problems from their own perspective.

\section{Discussion and teaching suggestions for improvement}

The research highlights, most of all, the importance of developing a climate of professional commitment towards the formation of active social educators, with the direct intervention of the pro-

[ 168 ] MARÍA VIOLETA ÁLVAREZ FERNÁNDEZ, VÍCTOR RAÚL PINTADO REY Y JOSÉ LUIS SAN FABIÁN MAROTO 
fesionales de intervención directa los que buscan soluciones y respuestas pragmáticas, que se acomodan a su realidad concreta.

Es el proceso de investigación-acción, por tanto, uno de los pilares principales del estudio, porque se convierte en un motor de búsqueda de soluciones compartidas que nos obliga a participar, a colaborar, a analizar sosegadamente nuestra intervención y planificar las nuevas sesiones acomodándolas al contexto y a las características de los jóvenes. Es esta búsqueda compartida de alternativas la que va generando un caldo de cultivo necesario para posteriormente poder realizar propuestas didácticas más eficaces, que contribuyan a mejorar los resultados del programa y asegurar un alto nivel de satisfacción de todos los participantes, confirmando la reducción de las reticencias de los jóvenes hacia estos programas de corte cognitivo (Fernández Gutiérrez, 2003).

Mateos-Aparicio (2009) plantea que las conclusiones de la investigación-acción hay que entenderlas como hipótesis de acción. Hipótesis que ofrecen alternativas interesantes a otros educadores y educadoras, invitándoles, por un lado, a comprobarlas y, por otro, a adaptarlas a su propia realidad educativa. Finalizamos, por tanto, compartiendo algunas de las reflexiones y propuestas didácticas que se han ido generando durante la investigación.

Cada día se hace más necesario revisar nuestros métodos de enseñanza en el campo de la educación social. Hay que elaborar nuevas propuestas que nos ayuden a dinamizar la intervención y generar experiencias que permitan a los jóvenes indagar, reflexionar, buscar y utilizar estrategias que les sirvan para reintegrarse con más posibilidades de éxito en la sociedad en la que viven. Esto exige intentar que los jóvenes con los que trabajamos digan, hagan y vean (Zambrano, 2005), ofreciéndoles actividades donde puedan emerger problemas, discrepancias, retos que les obliguen a elaborar nuevas alternativas, a replantearse valores y formas de actuar, originando un cambio que les pueda llevar a construir un nuevo proyecto de vida al margen de su carrera delictiva.

Es necesario acomodar cualquier propuesta metodológica que hagamos al grupo de jóvenes con los que vamos a trabajar. Tenemos que partir de lo que ya conocen, relacionando las ideas, estrategias y valores que creemos importantes para su reeducación fessionals themselves in the process of searching for pragmatic solutions and answers that fit their reality.

It is the process of action research proper, and therefore, one of the main pillars of this study, because it converts into a search engine for obtaining shared solutions that compels us to participate, to contribute, to calmly analyze our intervention and arranging them plan new session to the context and characteristics of the adolescents. This shared search for alternatives gradually generates the cultivation necessary for subsequently make more effective educational propositions, that help improve program results and ensure a high level of satisfaction of all participants, confirming the lowering of the reluctance of the youth towards these programs of cognitive kind (Fernández Gutiérrez, 2003).

Mateos-Aparicio (2009) argues that conclusions in active research must be understood as action hypothesis. They are hypothesis that offer interesting alternatives to other educators, inviting, on one hand, to test them and, on the other, to adapt them to their own educational reality. We conclude, therefore, sharing some of the ideas and teaching suggestions that have emerged during the investigation.

We must revise our teaching methods in the field of social education. We must develop new proposals to help us energize the intervention and create experiences that enable the youth to question, reflect, find and utilize strategies that may serve to reintegrate with higher chances to succeed in the society in which they live. This requires us to help the youth we work with to speak, act and observe (Zambrano, 2005), offering activities in which may emerge problems, disagreements, and challenges that impel them to develop new alternatives to rethink values and behaviors, resulting in changes them can lead the construction of a new life project regardless of his criminal past.

Adaptation of methodologies in always necessary in any educational proposition implemented with the youth which we work. We must build on what they know, relating the knowledge they possess with the ideas, strategies and values we believe are important for their education. This forces 
con las que ya poseen. Esto obliga al educador a conocer en profundidad las características del educando y los contenidos que va a impartir, para poder estructurarlos y secuenciarlos, consiguiendo que el aprendizaje tenga sentido para el joven; porque necesitamos una actitud favorable por parte del educando, una motivación y predisposición para aprender.

El proceso de enseñanza-aprendizaje debe convertirse en una propuesta que les resulte, en parte, gratificante, un proyecto ilusionante, con aprendizajes que tengan sentido y utilidad para ellos, intercalando contenidos socioeducativos con vivencias y emociones personales. La tarea tiene que permitirles demostrarse a sí mismos que son capaces de aprender y de cambiar, reforzando su autoestima y seguridad.

No podemos olvidar tampoco que exigir esfuerzo a los jóvenes es exigirnos a nosotros mismos compromiso, implicación y esfuerzo personal. Si creemos que perdemos el tiempo enseñando, ¿por qué van a perder ellos el tiempo aprendiendo? (Gruwell y Freedom Writer, 2007).

Este compromiso profesional tendrá que ir dirigido a generar nuevos contextos de aprendizaje, más flexibles y diversos, en los que podamos conjugar distintos tiempos, espacios y tipos de agrupamiento (individual, individual con apoyo de educador, pequeño grupo, gran grupo, etc.). Es decir, no nos podemos conformar con dar una respuesta estándar y general, debemos ofrecer propuestas diferenciadas, flexibilizando los contextos de aprendizaje, para poder diversificar nuestras actuaciones dentro de la propia sesión. La idea es que cada uno realice una tarea que pueda asumir, una pregunta que pueda responder, para que emerjan nuevos interrogantes, nuevas soluciones, que les permitan percibir la necesidad de cambiar sus conductas delictivas por otras prosociales.

Es importante buscar metodologías de intervención que favorezcan un clima de convivencia adecuado en los Centros de Responsabilidad Penal de Menores. El reglamento (R.D. 1774/2004) es una herramienta necesaria que nos proporciona la legislación, pero insuficiente por sí sola para generar ese ambiente de sosiego, relajado y productivo que requiere una intervención educativa eficaz y provechosa.

A este respecto, algunas alternativas didácticas que nos ayudaron a mejorar el clima de trabajo fueron las siguientes: ser preciso y riguroso en las instrucciones dadas para la realización de las actividades, ofreciendo the educator to know in depth the characteristics of the learner and the subject he/she will teach, to structure and ordinate them in a way that learning makes sense to the adolescents, because we need a positive attitude coming from them, with motivation and willingness to learn.

The teaching-learning process must become a proposition that turns out to be at least partially rewarding, an exciting project with lessons that have meaning and are useful to them, intercalating socioeducational matters along with personal and emotional experiences. The task should allow them to prove to themselves that they are able to learn and to change, strengthen self-esteem and security.

We should not forget that to require the youth such efforts is to lead ourselves into our own commitment, involvement and personal efforts. If we believe that we waste our time teaching, why should day waste time learning? (Gruwell and Freedom Writer, 2007).

This professional commitment must point towards the creation of new more flexible and diverse learning environments, where we can combine different times, spaces and group forms (individual, individual teacher support, small group, large group, etc..) . That is, we can not settle with standard and generic answers, we must offer different educational propositions, flexible learning environments, in order to diversify our activities within the session itself. The idea is that each member points out a task that he/she can be responsible for, a question he/she may answer, so to help emerge new inquirers, new solutions that enable them to perceive the need to exchange their criminal behavior for one of pro-social kind.

It is important to search for methodologies of intervention that foster an atmosphere of appropriate coexistence in the Centers for Juvenile Criminal Responsibility. The regulations (RD 1774/2004) is a necessary tool that gives us the legislation, but it is insufficient by itself to generate a calm and relaxed atmosphere which productive educational intervention requires in order to be effective and beneficial.

In effect, some educational alternatives that helped us to improve the working environment were: to be precise and rigorous in the instructions for carrying out the activities, offering short and clear ex-

[ 170 ] MARÍA VIOLETA ÁLVAREZ FERNÁNDEZ, VÍCTOR RAÚL PINTADO REY Y JOSÉ LUIS SAN FABIÁN MAROTO 
explicaciones cortas y claras; preparar las sesiones con antelación, organizando contenidos, métodos y situaciones de interacción; estructurar cuidadosamente los distintos espacios y tiempos que exige la tarea; reducir el periodo de exposición magistral y fomentar la participación ordenada y activa, asegurando el protagonismo de todos y ofreciendo a cada cual un espacio de expresión y atención.

Somos conscientes de que la didáctica es sólo un ámbito más a tener presente, pero un ámbito importante que con frecuencia descuidamos en la educación social y que, sin embargo, puede contribuir de forma importante a mejorar nuestra intervención, potenciando la eficacia de los programas socioeducativos para jóvenes en situación de riesgo social. planations; preparing the sessions in advance, organizing the subjects, methods and interactive situations, carefully structuring the different spaces and periods that the task demands, reduce the periods of expositive explanation and encourage orderly and active participation, ensuring the each and everybody's protagonism and offering to all adolescents involved a place for expression and attention.

We realize that teaching is just one of many aspects of this process to keep in mind, but it is an important dimension of it that is often neglect in Social Education and which, nonetheless, may bring significant contribution to improving our intervention, energizing the effectiveness of social and educational programs for adolescents under social risk.

\section{Bibliografía / References}

Alba, J.L. et al. (2005). El programa del pensamiento prosocial. Versión corta para jóvenes. In V. Garrido \& Ma. J. López. (coords.), Manual de intervención educativa en readaptación social. Vol.2. Los programas del pensamiento prosocial. (pp. 95-310). Valencia: Tirant lo Blanch.

Alba, J.L et al. (2006). Instrumentos de investigación para evaluar el Programa de Pensamiento Prosocial Versión Corta para Jóvenes. Valencia: Inédito.

Feliz Murias, T.; Sepúlveda Barrios, F. \& Gonzalo Fernández, R. (2008). Didáctica General para educadores sociales. Madrid: McGraw-Hill.

Fernández Gutiérrez, A. M. (2003). La intervención socioeducativa como proceso de investigación. Una experiencia de reflexión-acción en Centros de Menores. Valencia: Nau Llibres.

Forés, A. \& Vallvé, M. (2002). Quan didàctica porta nom d'educació social. Barcelona: Fundación Pere Tarrés.

Gruwell, E. \& Freedom Writer (2007). Diarios de la calle. Barcelona: Elipsis Ediciones.

López, M. J. \& Garrido, V. (2005). Un modelo para la prevención e intervención de la conducta antisocial. In V. Garrido \& M. J. López (coord.), Manual de intervención educativa en readaptación social. Vol.2. Los programas del pensamiento prosocial (pp. 11-94). Valencia: Tirant lo Blanch.

Mateos-Aparicio, J. M. (2009). Evaluación de la efectividad de programas destinados a la promoción y mejora de la convivencia en un centro de educación secundaria de la provincia de Ciudad Real. Tesis Doctoral. Burgos: Universidad de Burgos.

McGuire, J. \& Priestley, P. (1995). Reviewing «What work's»: Past, present and future. En J. McGuire, (ed), What works: Reducing reoffending: Guidelines from research and practice. Chichester: Wiley.

McKillip, J. (1989). Need Analysis. Tools for the Human Services and Education. London: Sage Publ.

Meirieu, P. (2006). Carta a un joven profesor. Por qué enseñar hoy. Barcelona: Graó.

Meirieu, P. (2007). Es responsabilidad del educador provocar el deseo de aprender. Cuadernos de pedagogía. 373 (noviembre), 42-47.

Meirieu, P. (2009). Aprender sí. Pero ¿cómo?. Barcelona: Octaedro.

O'Connor, J. \& Seymour, J. (2003). PNL para formadores. Barcelona: Urano.

Parcerisa, A. (2004). Didáctica en la educación social. Enseñar y aprender fuera de la escuela. Barcelona: Graó.

Parcerisa, A., Giné, N. \& Forés, A. (2010). La Educación Social. Una mirada didáctica. Relación, comunicación y secuencias educativas. Barcelona: Graó.

Pérez-Campanero, M. P. (1991). Cómo detectar las necesidades de Intervención Socioeducativa. Madrid: Narcea.

Pérez de Guzmán, M. V., Amador, L.V. \& Vargas, M. (2011). Resolución de conflictos en las aulas: un análisis desde la Investigación-Acción. Pedagogía Social. Revista Interuniversitaria, 18, 99-114.

Richardson, L. (1997). Fields of play: Constructing an academic life. New Brunswick NJ: Rutgers University Press. 
Stufflebeam, D.L. \& Shinkfield, A.J. (2005). Evaluación sistemática. Guía teórica y práctica. Barcelona. Paidós y M.E.C.

Zambrano, A. (2005). Philippe Meirieu. Trayectoria y formación del pedagogo. Educere -ldeas y personajes de la educación latinoamericana y universal-. Año 9, 30 (julio-agosto-septiembre), 431-442. Retrieved from http://www.saber.ula.ve/handle/123456789/19986

\section{CÓMO CITAR ESTE ARTÍCULO / HOW TO CITE THE ARTICLE}

Álvarez Fernández, M. V., Pintado Rey, V. R. \& San Fabián Maroto, J. L. (2014). Elaboración de propuestas didácticas orientadas a mejorar los programas socioeducativos para jóvenes en situación de riesgo social. Pedagogía Social. Revista Interuniversitaria, 23, 151-172. DOI: 10.7179/PSRI_2014.23.6

Álvarez Fernández, M. V., Pintado Rey, V. R. \& San Fabián Maroto, J. L. (2014). Making didactic proposals aimed at improving socioeducational programs for youngsters at risk of social exclusion. Pedagogia Social. Revista Interuniversitaria, 23, 151-172. DOI: 10.7179/PSRI_2014.23.6

Fecha de recepción del artículo / received date: $23 . \mathrm{VIII.2012}$

Fecha de revisión del artículo: / reviewed date: 11.IV.2013

Fecha de aceptación final / accepted date: 25.VI.2013

\section{DIRECCIÓN DE LOS AUTORES/ AUTHOR' ADDRESSES}

María Violeta Álvarez Fernández y Víctor Raúl Pintado Rey.

Departamento de Ciencias de la Educación. Área de Teoría e Historia de la Educación. Facultad de Formación del Profesorado y Educación. Campus de Llamaquique. C/ Aniceto Sela, s/n, 33005 Oviedo (Asturias) España. Universidad de Oviedo. TIf.: 985103399 / 9851030 81. Fax: 985103424 / 16.

Correo electrónico/e-mail: violeta@uniovi.es, rpintado@telecable.es

José Luis San Fabián Maroto. Departamento de Ciencias de la Educación. Área de Didáctica y Organización Escolar. Facultad de Formación del Profesorado y Educación. Campus de Llamaquique. C/ Aniceto Sela, s/n, 33005 Oviedo (Asturias) España. Universidad de Oviedo. Tlf: 985103399 / 98510 30 81. Fax: 985103424 / 16. Correo electrónico/e-mail: jlsanfa@uniovi.es

\section{PERFIL ACADÉMICO / ACADEMIC PROFILE}

María Violeta Álvarez Fernández: Titular de Escuela Universitaria Departamento de Ciencias de la Educación de la Universidad de Oviedo. Profesora del área de Teoría e Historia de la Educación. Titulada en pedagogía ha participado numerosos proyectos de investigación en el campo de la educación social y en el ámbito de la política y la legislación educativa.

Víctor Raúl Pintado Rey: Profesor Asociado de la Universidad de Oviedo. Departamento de ciencias de la Educación de la Universidad de Oviedo. Doctor en Pedagogía por la Universidad de Oviedo. Titulado en pedagogía y magisterio ha participado numerosos proyectos de investigación en el campo de la educación social. Maestro de Educación Infantil. Educador Social. No de colegiado: 2049. Colegio Profesional Educadores Sociales Andalucía-.

José Luis San Fabián Maroto: Catedrático de universidad por el Área de Didáctica y Organización Escolar. Titulado en pedagogía y sociología, ha participado numerosos proyectos de investigación en los campos de la formación docente, organización y gestión de instituciones educativas, evaluación de programas e instituciones, pedagogía social, participación educativa, estudios sociales de la infancia, docencia universitaria habiendo dirigido 18 tesis doctorales y publicado numerosos trabajos relacionados con los citados temas. Ha sido director del Curso de Postgrado en Pedagogía Social y actualmente dirige el Máster oficial de Intervención e Investigación Socioeducativa.

[ 172 ] MARÍA VIOLETA ÁLVAREZ FERNÁNDEZ, VÍCTOR RAÚL PINTADO REY Y JOSÉ LUIS SAN FABIÁN MAROTO SIPS - PEDAGOGIA SOCIAL. REVISTA INTERUNIVERSITARIA [1139-1723 (2014) 23, 151-172] TERCERA ÉPOCA 